MAKALAH

\title{
PASAR PERSAINGAN MONOPOLISTIK DAN OLIGOPOLI
}

Makalah Ini Disusun Untuk Memenuhi Tugas pada Mata Kuliah Ekonomi Mikro Syariah

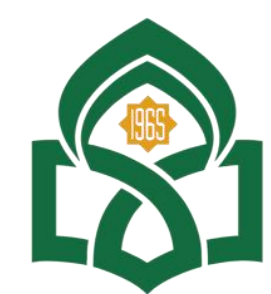

UNIVERSITAS ISLAM NEGERI

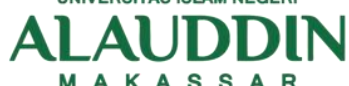

Dosen Pengampu:Samsul Arifai,S.A.B.,MA.

Disusun Oleh

\section{Kelompok 10:}

Khelvin. K $\quad(905012118)$

Nur Anisa $\quad$ (90500120088)

Zahra Amaliyah Rusdin ～～（90500120104)

Nur Khairunnisa $\quad$ (90500120110)

PRODI PERBANKAN SYARIAH

FAKULTAS EKONOMI DAN BISNIS ISLAM

UNIVERSITAS ISLAM NEGERI ALAUDDIN MAKASSAR

TAHUN 2021 


\section{KATA PENGANTAR}

Puji syukur kehadirat Allah SWT yang telah memberikan rahmat dan hidayah-Nya sehingga kami dapat menyelesaikan tugas makalah yang berjudul " Pasar Persaingan Monopolistik dan Oligopoli “ ini dengan tepat waktu.adapun tujuan dari makalah ini adalah untuk memenuhi tugas pada mata kuliah Ekonomi Mikro Syariah.Selain itu,makalah ini bertujuan untuk menambah wawasan tentang Pasar Monopolistik dan Oligopoli bagi para pembaca dan juga penulis.

Kami mengucapkan terima kasih kepada Bapak Samsul Arifai ,selaku dosen yang telah memberikan tugas ini sehingga dapat menambah pengetahuan dan wawasan sesuai bidang yang kami tekuni.

Makalah yang kami tulis ini masih jauh dari kata sempurna.Oleh karena itu,kritik dan saran yang membangun akan kami nantikan demi kesempurnaan makalah ini.

Gowa,22 - Nov-2021

Penulis 


\section{DAFTAR ISI}

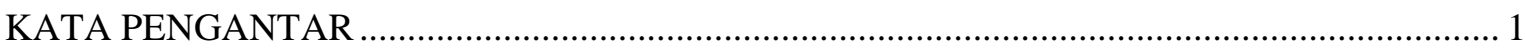

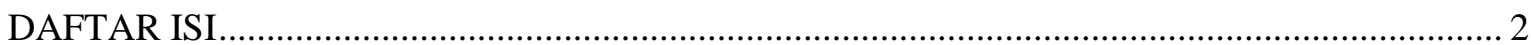

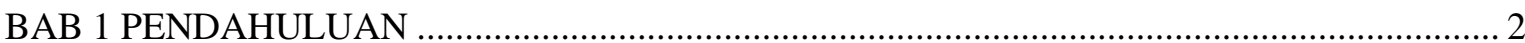

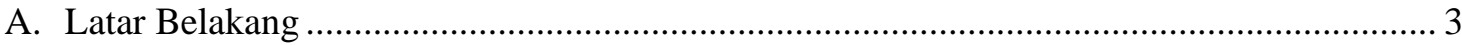

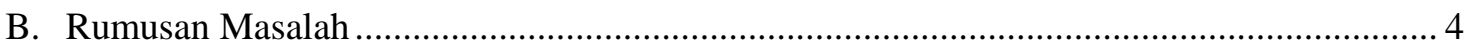

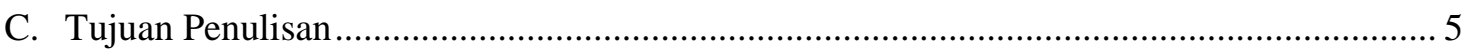

BAB II PEMBAHASAN

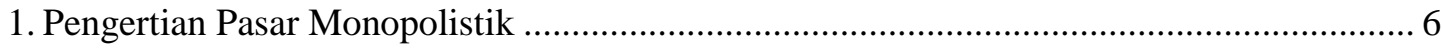

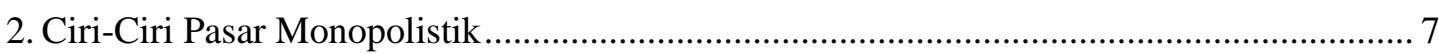

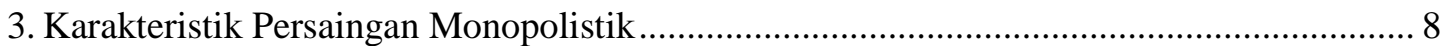

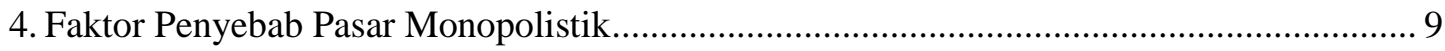

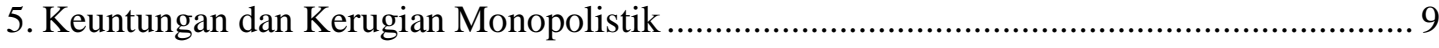

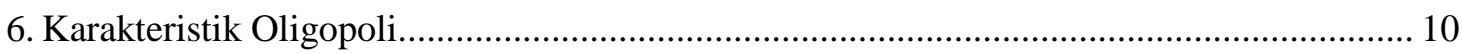

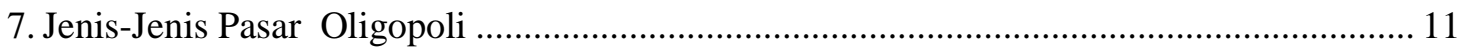

8. Perspektif Islam Terhadap Pasar Monopoli ........................................................................... 12

\section{BAB III PENUTUP}

A. Kesimpulan

Daftar Pustaka 


\section{BAB I}

\section{PENDAHULUAN}

\section{A.Latar Belakang}

Dalam kehidupan sehari-hari bisa dipastikan bahwa kita memerlukan berbagai kebutuhan hidup yang tidak bisa kita peroleh secara langsung dari alam.Oleh karena itu,untuk memenuhi kebutuhan kita melakukan proses jual beli baik itu dipasar maupun tempat yang bisa digunakan untuk proses jual beli.

Persaingan dalam dunia bisnis merupakan suatu dinamika tersendiri yang tidak dapat dihindari.Bagi beberapa pebisnis,persaingan berkonotasi negatif karena bisa mengancam bisnis karena takut akan berkurangnya profit atau konsumen lebih memilih harga rendah dari pesaing.Namun pada kenyataannya tidak demikian.Persaingan yang sehat dapat memberikan hal yang baik bagi pebisnis,pesaing itu sendiri dan bahkan para pelanggan. Pasar monopoli timbul akibat adanya praktek monopoli,yaitu pemusatan kekuatan ekonomi oleh satu pelaku usaha atau penjual yang mengakibatkan dikuasainnya produksi dan atau pemasaran atas barang dan jasa tertentu.pada saat sekarang perusahaan yang seratus persen yang bersifat monopoli jarang di temui,mungkin hanya beberapa komoditi jasa seperti telpon,listrik,dan air yang benar-benar dikuasai oleh penjual tunggal di Indonesia dipegang oleh peruusahaan pemerintah.

B.Rumusan Masalah

1. Apa yang dimaksud dengan pasar persaingan monopolistik

2. Apa -apa yang termasuk dalam ciri-ciri pasar monopolistik

3. Bagaimana karakteristik pasar monopolistik

\section{C.Tujuan Penulisan}

1. Untuk mengetahui apa itu pasar persaingan monopolistik

2. Untuk mengetahui ciri-ciri pasar monopolistik

3. Untuk mengetahui karakteristik pasar monopolistik 


\section{BAB II}

\section{PEMBAHASAAN}

\section{A.Pengertian pasar persaingan monopolistik dan oligopoli}

Pasar monopolistik ialah sebuah sistem pasar yang dimana terdapat banyak produsen atau perusahaan didalamnya yang mempunyai barang atau jasa sama dengan perusahaan lainnya akan tetapi tetap memiliki beberapa aspek pembeda seperti warna produk bentuk hingga spesifikasi yang disajikan ,produsen di pasar monopolistik sangat banyak namun setiap produk yang ada tetap mempunyai ciri khas masing -masing sebagai pembeda.

Dalam buku Teori Ekonomi (pendekatan mikro) menjelaskan pula bahwa pasar monopolistik adalah pasar dengan banyak produsen yang menghasilkan komoditas berbeda karakteristiknya .Dan pada jenis pasar ini,produsen menawarkan satu jenis barang dengan berbagai ciri produk yang berbeda-beda dari segi kualitas,bentuk,dan ukuran.Sehingga pada pasar monopolistik ini ,harga bukanlah menjadi faktor penentu angka penjualan melainkan bagaimana perssepsi masyarakat terhadap produk yang dijual.Oleh sebab itu,perusahaan di pasar ini harus aktif dengan melakukan promosi terhadap produknya serta terus menjaga citra perusahannya. Sedangkan pasar oligopoli adalah tempat jual beli yang terdiri dari beberapa macam jenis perusahaan, "sehingga perilaku dari salah satu perusahaan cenderung akan berpengaruh secara drastis terhadap pengusaha“ yang lain yang ikut didalamnya . Dan akhirnya akan ada sifat yang saling ketergantungan di antara perusahaan satu dengan perusahaan yang lainya yang ikut didalam pasar oligopoli. Sebagai contoh jika perusahaan pertama menurunkan nominal harga dan perusahaan kedua tidak menurunkan nominal harga, maka perusahaan .Perusahaan yang kedua tidak menurunkan harga cenderung akan kehilangan pelanggan secara drastis. Di beberapa macam bentuk pasar persaingan tidak sempurna, para pelaku dalam pasar oligopoli cenderung menunjukkan perilaku berkompetitif yang paling berat. Sebelum mengambil suatu keputusan atau langkah, sebuah perusahaan akan memperhitungkan atau menunggu reaksi dari para pesaingnya. Tidak heran jika permainan dalam suatu pasar oligopoli mirip dengan permainan catrur atau skak. dan Jika perusahaan atau pengusaha mengambil langkah secara benar, maka perusahaan akan 
mendapatkan keuntungan atau gain berlipat ganda, akan tetapi jika perusahaan atau pengusaha salah dalam mengambil kebijakan, perusahaan bisa bangkrut atau tidak ada pemasukan kedalam perusahaan tersebut. Secara harfiah"oligopoli"berarti hanya ada beberapa penjual di pasar. Boleh dikatakan oligopoli merupakan bagian tengah dari monopolystyc competition.

\section{B.Ciri-ciri pasar monopolistik dan oligopoli}

1. Banyaknya penjual di pasar.

Pasar monopolistik tidak mempunyai produsen atau penjual sebanyak pasar persaingan sempurna dan tidak ada produsen atau perusahaan yang mempunyai skala produksi lebih besar dari Perusahaan lainnya .

2. .Produk serupa tapi tak sama .

Jika dilihat sekilas suatu produk atau jasa yang ada akan terlihat sebuah cirikhas dari perusahaan atau produsen penyedia barang atau jasa tersebut dan terlihat perbedaanya antara produk perusahaan A dan produk perusahaan B,sehingga produk atau jasa pada industri pasar monopolistik tidak masuk kategori barang pengganti sempurna akan tetapi masuk kategori barang pengganti dekat atau sementara.

3. Harga.

Setiap perusahaan tidak mempunyai kemampuan penuh untuk merubah atau mempengaruhi harga karna akan merusak pasar monopolistik.

Keluar masuk pasar. Dalam pasar Monopolistik setiap orang bebas untuk masuk atau keluar dalam pasar tersebut sesuai kemampuan perusahaan untuk bertahan dalam persaingan.

4. Keluar masuk pasar.

Dalam pasar Monopolistik setiap orang bebas untuk masuk atau keluar dalam pasar tersebut sesuai kemampuan perusahaan untuk bertahan dalam persaingan.

5. Promosi.

Iklan atau promosi sangat mempengaruhi kemampuan sebuah produsen atau perusahaan dalam bertahan di dlam persaingan pasar monopolistik. ${ }^{1}$

\footnotetext{
${ }^{1}$ Emmility. (2011). Ekonomi monopolistik islam, Vol.1, No.2, Feb 2011, 72-139.
} 
Adapun ciri dari pasar Oligooli yaitu sebagai berikut :

1. Terdapatabeberapa pengusahal pada pasar ini(pada umumnya dengan kurang dari 10) degan banyakapembeli pada pasar ini .

2. Barangayang dijula belikan biasanya yaitu homogen atau seragam akan tetapi berbeda atau terdiferensiasi Contohnyaayaitu rokok dengan berbagai aneka rasa, telepon seluleradengan adanya berbagai macam teknologi canggih dengan berbagai macam tampilan, dan lain lain.

3. Pengusaha di pasar oligopoli biasanya memiliki keterampilan dalam menentukan nominal harga suatu barang atau jasa karena dengan adanya perbedaan antarai peroduk satu dengan produk lain yang ditawarkan .

4. Para pengusaha bersaing sangat komplek antara pengusaha satu dengan pengusaha lainnya. Persaingan terutama melalui gerakan marketing secara bombastis dengan tentunya perang harga. Perang harga yang dimaksud disini yaitu terjadi ketika perusahaan pertama bermaksud untuk menurunkan nominal harga agar memperoleh konsumen atau pembeli pasar yang lebih besar, namun di ikuti dengan penurunan nominal harga oleh perusahaan pesaing sehingga pada akhirnya konsumen“atau pembeli pada pasar yang diperoleh oleh para perusahaan adalah tetap ,namun dengan harga jual yang lebih rendah.

5. Pengusaha baru dapat terjun kedalam pasar oligopoli ini meskipun sulit dalam bersaing. didalam pasar oligopoli dibutuhkan modal besar untuk bersaing. Apabila perusahaan yg lebih dulu berada dipasar ini kemudian perusahaan ini menurunkan nominal harga secara signifikan (predatory pricing) hal inilah yang membuat perusahaan baru ini sulit bertahan dalam pasar ini.

\section{C.Karakteristik persaingan monopolistik}

Di dalam sistem sturuktur pasar monopolistik mempunyai beberapa karakteristik diantaranya yaitu :

a. Produk Diferensiasi.

Produk diferensiasi adalah usaha memberikan perbedaan pada produk yang dihasilkan oleh produsen atau perusahaan untuk memberikan suatu 
daya tarik ke konsumen sehingga konsumen lebih memilih produk yang dihasilkan perusahaan tersebut daripada produk yang dihasilkan oleh perusahaan lain.

b. Jumlah Produsen yang sangat banyak.

Produsen atau perusahaan di sistem pasar monopolistik sangat banyak,bisa dilihat dengan begitu banyaknya merk pakaian hingga barang primer lainnya,dikarenakan banyak produk yang sama maka setiap perusahaan harus memperhatikan output harga agar tidak mempengaruhi perusahaan lainnya.

c. Mudah masuk dan keluar Dikarenakan melimpahnya sumber daya dan peluang bisnis yang terbuka lebar sehingga banyak orang yang ingin masuk dalam pasar monopolistik akan tetapi hal itu di imbangi dengan kerasnya persaingan sehingga banyak sekali produsen yang keluar masuk pasar monopolistik.

\section{D.Faktor penyebab pasar monopolistik}

Pasar Monopolistik tidak tercipta begitu saja,ada beberapa faktor yang mempengaruhi terbentuknya pasar monopolistik yaitu :

1) .Ketidakpuasan terhadap pasar sempurna dan monopoli Dikarenakan produsen yang tidak puas dengan sistem pasar sempurna dan pasar monopoli sehingga banyak sekali produsen atau perusahaan yang berpindah ke sistem pasar monopolistik.

2) Sumber alam Sumber daya alam yang amat sangat melimpahruah di Indonesia membuat setiap orang atau produsen mudah terjun dalam industri monopolistik,karena sangat mudah untuk mencaribahan baku maupun bahan pendukung dalam produksi suatu barang.

3) Produk diferensial dikarenakan produk diferensial yang tidak terlalu tinggi membuat setiap produsen lebih mudah dalam persaingan non harga.

\section{E.Keutungan dan Kerugian pasar monopolistik}

Kerugian :

a) Memerlukan modal yang sangat besar karena perusahaan yang sudah lebih dulu masuk ke pasar monopolistik dan sukses mempunyai skala ekonomi yang besar dan digunakan untuk produksi sampai promosi 
b) Memiliki skala dan tingkat persaingan yang cukup luas dan tinggi dalam bidang kualitas harga dan jasa pelayanan,jadi produsen atau perusahaan baru harus siap dengan persaingan yang terjadi dalam sistem pasar monopolistik

c) Setiap perusahaan harus melakukan inovasi pada produknya sehingga tidak akan kalah dengan perusahaan lainnya dibidang yang sama akan tetapi hal ini akan meningkatkan baiya produksi yang berpengaruh pada output harga produk yang harus dibayar konsumen .

d) Untuk perusahaan kecil atau yang baru masuk pasar monopolistik tingkat keoptimalan atau efisiensi bisa dibilang cukup rendah .

e) Karena kurang efisienya suatu produk dan produksi di perusahaan kecil maka harga produk juga akan semakin murah dan mempengaruhi biaya operasional suatu perusahaan .

f) Terdapat kemungkinan akan terjadi pemborosan biaya produksi pengiklanan dan hallainnya dalam pasar monopolistik hal ini sangat berbanding terbalik dengan sistem pasar persaingan sempurna dan monopolistik.

Keuntungan:

1) Kebebasan setiap produsen atau perusahaan untuk keluar dan masuk sistem pasar monopolistik membuat setiap perusahaan selalu melakukan inovasi jika tidak ingin kehilangan konsumen.

2) Sangat banyaknya produsen dan produk membawa keuntungan untuk konsumen karena konsumen akan mempunyai banyak opsi pilihan produk sesuai kebutuhan dan pastinya mempunyai kesempatan untuk memilih produk terbaik yang ada .

3) Karena kebutuhan sehari-hari tersedia didalam sistem pasar monopolistik ini sehingga konsumen lebih mudah untuk menemukannya .

4) Diferensiasi produk atau perbedaan produk membuat para konsumen benar-benar berhati-hati dan selektif untuk memilih suatu produk dan biasanya konsumen akan menjadi konsumen tetap produk tersebut.

\section{F.Karakteristik Oligopoli}

1. Dijalankan dua produsen atau lebih

Ciri -ciri pasar oligopoli yang pertama adalah dijalankan dua produsen atau lebih.sedangkan batas jumlahnya adalah kurang dari sepuluh produsen atau pihak penyedia barang.

Karena ciri-ciri inilah pasar jenis ini disebut persaingan tidak sempurna disebabkan jumlah produsen yang menjual produk sangat sedikit.Tentu 
berbeda dengan produsen teknologi yang jumlahnya banyak sehingga persaingannya yang maksimal.

2. Produk yang dijual homogen dan saling menggantikan

Ciri- ciri pasar oligopoli yang kedua adalah produk yang dijual homogen dan bisa saling menggantikan.Salah satu contohnya adalah produk rokok.yang mana produk yang dijual hanya satu rokok,tetapi variasi produknya banyak.

3. Kebijakan produsen utama sebagai acuan produsen lainnya .

Di dalam pasar oligopoli kebijakan produsen utama menjadi acuan produsen lainnya (produsen cabang ).Oleh karena itu,pihak produsen cabang hanya menjalankan saja kebijakan tersebut.

Yang termasuk ke dalam kebijakan produsen utama yang harus diikuti produsen lainnya adalah penarikan produk lama dan digantikan oleh produk yang baru.termasuk juga penggantian fungsi,harga,dan rasa dari produk.

4. Harga barang di pasar relatif sama

Ciri ciri yang selanjutnya adalah harga barang di pasar relatif sama.sekalipun ada perbedaan,selisihnya tidak terlalu besar.misal,harga sabun merek A di toko intan harganya tidak akan jauh berbeda dengan harga sabun merek yang sama di toko barokah .

Ini disebabkan oleh kebijakan naik turunnya harga ditentukan oleh produsen turunnya harga ditentukan oleh produsen utama.sehingga produsen yang di bawahnya akan menyesuaikan dengan harga-harga tersebut.karena jumlah produsennya tidak terlalu banyak,tentu selisih harga yang muncul di pasaran juga tidak terlalu besar.

5. Produsen baru kesulitan masuk pasar

Produsen baru akan sangat kseulitan untuk memasuki pasar oligopoli.karena produsen yang lama sudah eksis dengan cara memainkan harga agar konsumen tidak berpindah .sedangkan produsen baru tentunya tidak akan bisa mengejar eksitensi tersebut.memang perusahaan bisa memberikan harga murah,tetapi sebagai usaha baru tentu sangat riskan,karena keuntungan yang didapatkan sangat kecil. 
6. Membutuhkan strategi pemasaran yang matang

Ciri-ciri terakhir jenis pasar ini adalah membutuhkan strategi pemasaran yang matang.karena produk yang dipasarkan homogen dengan jumlah produsen yang sedikit.Dikhawtirkan jika sosialisasi pasar tidak dilakukan dengan intensif,konsumen akan berpindah ke produk lain.

Oleh sebab itu,promosi atau strategi marketing perlu untuk dijalankan dengan baik.karena ini yang menentukan produk masih beredar atau malah tenggelam.

\section{G.Jenis -Jenis pasar oligopoli}

1. Pasar oligopili murni (homogen )

Jenis yang pertama adalah pasar murni atau homogen.maksudnya adalah produk yang dipasarkan hanya satu macam tetapi variasinya banyak alias beragam.selain itu,jenis ini memiliki ciri-ciri perbedaan harga tidak terlalu signifikan.

Oligopoli murni juga ada kecenderungan berpatokan pada satu produsen.jika produsen ini menaikkan harga,maka produsen yang lainnya juga ikut melakukan hal yang sama .

2. Pasar oligopoli terdiferensiasi

Jenis yang selanjutnya adalah pasar terdiferensiasi .ciri-ciri adalah produsen tetap menjual produk homogen tetapi persoalan harganya tidak berpatokan kepada produsen yang lainnya .

Sehingga ada kemungkinan produsen tidak menaikkan harga sekalipun produsen lain harga produknya sudah meningkat. Bisa juga sebaliknya ,produsen menaikkan harga justru ketika produsen lain harganya masih stagnan.

3. Pasar oligopoli non kolusi

Jenis yang ketiga adalah pasar non kolusi.jenis ini maksudnya adalah produsen yang akan memainkan harga tetapi dengan membaca perkembangan produsen lainnya sebagai pesaing usaha.

Salah satu tujuan produsen mandiri semacam ini ialah,mencoba eksis dengan harga yang dimainkan sendiri setelah yakin produsen yang lain tidak akan mengikuti jejaknya.biasanya produsen ini sudah mempelajari penyebab keputusan dinaikkannya harga produk atau sebaliknya. 
4. Pasar oligopoli kolusi

Jenis pasar yang terakhir adalah pasar kolusi.maksudnya adalah kerjasama produsen dengan produsen lainnya untuk menaikkan harga bersama-sama atau membiarkannya stagnan. Ini merupakan kebalikan dari pasar oligopoli non kolusi yang mana setiap produsen mencari celah menaikkan atau menurunkan harga tanpa diketahui produsen yang lain.

\section{H.Perspektif islam terhadap pasar monopolistik}

Monopolistik dalam perspektif ekonomi Islam memiliki pengertian yang berbeda dengan monopolistik dalam perspektif ekonomi konvensional. Dalam perspektif ekonomi Islam secara etimologi monopolistik (ihtikâr) berasal dari kata alhukr yang artinya al-zhulm wa al-'isâ'ah al-mu'âsyarah, yaitu berbuat aniaya dan sewenang-wenang.

Jumhur ulama berpendapat bahwa monopoli hukumnya haram sebagaimana dikemukakan oleh ulama kalangan Hanâbilah, Mâlikiyyah, Hanafiyyah, dan mayoritas Syâfi'iyyah. Argumentasi yang mereka bangun adalah dalil naqlî dan 'aqlî. Di antara dalil naqlî yang mereka jadikan landasan hukum adalah Alquran dan Sunah. Allah Swt. berfirman dalam surah al-Hajj [22] ayat 25 yang berbunyi : "Sesungguhnya orang-orang yang kafir dan menghalangi manusia dari jalan Allah dan Masjidil Haram yang telah Kami jadikan untuk semua manusia, baik yang bermukim di situ maupun di padang pasir dan siapa yang bermaksud di dalamnya melakukan kejahatan secara zalim, niscaya akan Kami rasakan kepadanya sebagian siksa yang pedih."

Argumentasi yang dibangun oleh ulama yang mengharamkan monopolistik (ihtikâr) tidak hanya bersumber dari dalil naql saja, akan tetapi 
bersumber pula dari dalil 'aql. Mereka mengemukakan bahwa monopoli sangat erat kaitannya dengan hajat orang banyak yang ketika salah satu pihak melakukannya akan menghambat pihak lain untuk memenuhi kebutuhannya, kalaupun dapat memenuhinya, mereka mendapatkannya dengan harga yang cukup tinggi. Htersebut merupakan kezaliman yang tidak bisa diteloransi. Ihtikâr hanya merea-alisasikan kemaslahatan individu, bukan kemaslahatan umum. apabila kemas-lahatan individu .

Namun tidak termasuk monopoli yang dilakukan pada situasi di mana pasokan barang melimpah ,misalnnya ketika terjadi panen besar, dan segera menjualnya ketika pasar membutuhkannya atau menimbun barang dengan tujuan untuk memenuhi kebutuhan keluarganya dan bukan untuk dijual dengan harga yang tinggi ketika masyarakat sangat membutuhkannya.16 Karena dalam situasi panen besar, apabila tidak ada pihak yang bersedia membeli/menampung hasil panen tersebut, maka harga yang terbentuk di pasar akan semakin melemah. Hal ini justru akan merugikan petani yang dalam hal ini merupakan pemasok terbesar.

${ }^{2}$ fattah, D. a. (2011). Monopoli dalam perspektif ekonomi islam, 1-22. 


\section{BAB III}

\section{PENUTUP}

\section{A.Kesimpulan}

Pasar monopolistik adalah pasar homogen atau berarti pasar dimana produsen dan konsumen hanya saling memenuhi kebutuhan barang yang sama atau sejenis tetapi setiap produsen mempunyai ciri khas produk masingmasing,dalam pasar monopolistik tingkat persaingan bisa dibilang sangat tinggi karena setiap perusahaan mempunyai produk yang sama dan biasanya berupa barang primer atau kebutuhan sehari-hari,setiap pengusaha sangat mudah masuk dan keluar dalam pasar monopolistik karena banyaknya sumber daya alam dan peluang yang cukup lebar,setiap perusahaan berlombalomba menciptakan produk terbaik yang sekilas sama tapi tetap mempunyai perbedaan .

Monopolistik dalam ekonomi Islam dikenal dengan istilah ihtikâr, yaitu upaya yang dilakukan oleh salah satu pihak dengan cara menimbun barang. Berbeda dengan ekonomi konvensional yang bukan hanya dengan menimbun saja, akan tetapi dengan banyak cara seperti kepemilikan suatu sumber daya yang unik (istimewa) yang tidak dimiliki oleh orang atau perusahaan lain, skala ekonomis dan lain sebagainya. Dengan demikian, apapun yang dilakukan pihak tertentu untuk mencari keuntungan dengan cara membuat kelangkaan suatu barang dikatakan monopoli (ihtikar) dalam perspektif ekonomi Islam. Definisidefinisi monopoli dalam perspektif konvensional yang tujuan dan motifnya menzalimi dan merugikan orang lain, maka dapat dikategorikan monopoli dalam perspektif. 


\section{DAFTAR PUSTAKA}

Emmility. (2011). Ekonomi monopolistik islam, Vol.1, No.2, Feb 2011, 72-139.

El munawwarah. (2021). Pasar monopoli dalam pandangan islam, vol 2 (E-ISSN: 27219275), 93-100.

fattah, D. a. (2011). Monopoli dalam perspektif ekonomi islam, 1-22.

nasution, M. e. (Penyunt.). (2014). H. Ahmad Afan Zaini, S.Pd., M.M., M.Pd.1. PASAR PERSAINGAN SEMPURNA, Vol IV, No. 2, Agustus 2014.

Samsul, S. (2019). Analisis Pemanfaatan harta dalam Konsumsi Masyarakat Ekonomi Konvensional dan Ekonomi Islam. Al-Azhar Journal of Islamic Economics, 1(2), 110-130. 